\title{
Prevalence of Potentially Pathogenic Free-Living Amoebae from Acanthamoeba and Naegleria Genera in Non-Hospital, Public, Internal Environments from the City of Santos, Brazil
}

\author{
Lais Helena Teixeira, Silvana Rocha, Rosa Maria Ferreiro Pinto, Marcos Montani Caseiro and Sergio Olavo Pinto da Costa \\ Catholic University of Santos; Santos, SP, Brazil
}

\begin{abstract}
Acanthamoeba and Naegleria species are free-living amoebae (FLA) found in a large variety of natural habitats. The prevalence of such amoebae was determined from dust samples taken from public non-hospital internal environments with good standards of cleanliness from two campuses of the same University in the city of Santos (SP), Brazil, and where young and apparently healthy people circulate. The frequency of free-living amoebae in both campuses was $39 \%$ and $17 \%$ respectively, with predominance of the genus Acanthamoeba. On the campus with a much larger number of circulating individuals, the observed frequency of free-living amoebae was 2.29 times larger $(P<0.00005)$. Two trophozoite forms of Naegleria fowleri, are the only species of this genus known to cause primary amoebian meningoencephalitis, a rare and non-opportunistic infection. We assume that the high frequency of these organisms in different internal locations represents some kind of public health risk.

Key-Words: Free - living amoebae, Acanthamoeba spp., Naegleria spp., prevalence, dust from internal environments, Brazil.
\end{abstract}

Free-living amoebae (FLA) are unicellular protozoa widely distributed on all continents that are able to survive and replicate in the environment without a host. FLA are present in a large variety of natural habitats, including lakes, rivers, swimming pools, thermal baths, tap water, sources of running water which receive industrial refuse, sewage, humid soils, dust, as well as fluids or tissue from healthy human oropharynx [1-4]. FLA feed on microorganisms with which they can maintain an endosymbiotic relationship. The cysts of these amoebae persist for many years, permitting them to survive in unfavorable environments. The cysts are very resistant to changes in temperature, $\mathrm{pH}$, chlorine, detergents and common disinfectants. Several species are able to cause infections that are considered either accidental (acute meningitis by Naegleria spp.), opportunistic (granulomatosis meningitis, otites and other diseases caused by Acanthamoeba spp.) or non-opportunistic (a serious primary amebian meningoencephalitis caused by Naegleria fowleri $[1,5]$. FLA can be found in hospitals, dialysis units, dental premises, as well as in eye drops and contact eye lens cleaning solutions, contaminated by bacteria or yeast [1]. Subclinical infections caused by these protozoa are probably common among healthy individuals, in whom protozoa harbored in the nose and throat can, in weaker periods, behave as facultative parasites [5,6]). In Brazil, cases of human diseases caused by these amoebae have been described [7-10] derived from water [11-14] and dust from external environments $[15,16]$. The few reports of FLA occurring in internal environments all involve hospitals $[1,18]$.

Received on 13 June 2009; revised 7 October 2009.

Address for correspondence: Dr. Sergio Olavo Pinto da Costa. Rua Dr. Mário Ferraz, 77/42, 01453-010, São Paulo, SP, Brazil. Phone: 5511 38199788-S.Paulo. Fax 5513 32260500-Santos,SP. E-mail: sopdcost@usp.br.

The Brazilian Journal of Infectious Diseases 2009;13(6):395-397. (C) 2009 by The Brazilian Journal of Infectious Diseases and Contexto Publishing. All rights reserved.
The present work evaluates the occurrence of free-living amoebae in dust from non-hospital internal environments, where a large number of young and apparently healthy people circulate.

\section{Material and Methods}

\section{Sampling of Material}

Dust was collected from the floors of buildings from two different campuses from the Catholic University of Santos, São Paulo, Brazil, namely D. Edílio José Soares (CDI) and Vila Nova (CVN), between May and September of 2007 with temperatures ranging from $20^{\circ} \mathrm{C}$ to $33^{\circ} \mathrm{C}$. These campuses differ with regards to the number of people that circulate daily. On the CDI, a total of 4,000 students and faculty circulate, while on the CVN, the corresponding total is approximately 186. The samples were collected in predominantly dry areas. The floors are kept constantly clean during the day and evening activities by using different types of commercial products based on chlorine, detergents and soaps.

One hundred dust samples from the floor from internal circulating areas were randomly collected from each campus using a sterilized swab, and then transferring to screw caps tubes (200x22 mm) containing $5.0 \mathrm{~mL}$ of Page saline solution, used to transport the material for analysis at a single university laboratory.

\section{Culturing}

The material in Page saline solution ( $2.5 \mathrm{mM} \mathrm{NaCl}, 1 \mathrm{mM}$ KH2PO4, 0.5 mM Na2HPO4, 40 mM CaCl2.6H2O e 20 mM $\mathrm{MgSO} 4.7 \mathrm{H2O}$ ) from the tubes have been transferred to tubes containing $5.0 \mathrm{~mL}$ of non-nutrient agar with $1 \%(\mathrm{w} / \mathrm{v})$ of Difco agar in Page saline solution and $50 \mu \mathrm{L}$ o BHI broth (Difco), inoculated with $0.1 \mathrm{~mL}$ of late log phase cultures of Gramnegative bacteria (E. coli ATCC 25922), and incubated at $30^{\circ} \mathrm{C}$. The observation of throphozoites was performed every 48hs for up to 20 days, by optical microscopy and $400 \mathrm{X}$ magnification. The positive samples were transferred to new tubes containing non-nutrient agar, in the same way described 
above. The identification of amoebae genera was based on the observation of cysts and throphozoites, according to type of movement and morphological criteria [20-22]. Formation of flagella in distilled water at $37^{\circ} \mathrm{C}$ and a temperature increase to $43^{\circ} \mathrm{C}$ made the culture media selective for Naegleria fowleri isolation [23].

\section{Sample Maintenance}

Amoebae kept in tubes containing non-nutrient agar with $1 \%(\mathrm{w} / \mathrm{v})$ of Difco agar in Page saline solution at $4^{\circ} \mathrm{C}$ under moist conditions were maintained for several months.

\section{Results}

Potentially pathogenic free-living amoebae from the genera Acanthamoeba and Naegleria were isolated from internal environments from two campuses of the investigated university.

On the CDI campus, among 100 samples of dust analyzed, $39 \%$ were positive according to observation of cystic and throphozoite structures. $19 \%$ of samples were positive for only Acanthamoeba, 12\% for only Naegleria and in $8 \%$, the simultaneous presence of both genera was observed.

On the CVN campus, among the 100 analyzed samples and using the same observational criteria, 17\% were positive. 11\% were positive for only Acanthamoeba, 5\% for only Naegleria, and in only $1 \%$ both genera were detected.

The presence of free-living amoebae on the CDI campus was 2.29 times larger $(p<0.00005)$ than in the $C V N$ campus.

In two samples from different locations on the CDI campus, the flagellated form of Naegleria fowleri was detected.

\section{Discussion}

Species of Acanthamoeba and Naegleria are widely distributed in the environment, and can be acquired by humans by contact with contaminated water or dust by either aspiration or inhalation [24]. Giazzi [15] evaluated the FLA prevalence in 23 dust samples from external environments and observed a high positive rate of $\sim 86 \%$ for the genus Acanthamoeba and $\sim 39 \%$ for Naegleria. In Brazil, several reports address FLA isolation from dust in hospitals, because of the potential pathogenicity of these organisms. SILVA \& ROSA [17] collected 132 dust samples in two hospitals. The positive rate was $\sim 46 \%$ for the Acanthamoeba and $\sim 4 \%$ for Naegleria genus. Carlesso et al. [18] analysed 135 samples in dust and biofilms from 15 different hospital environments, and detected a 35\% positive rate, with 34\% with morphological aspects of amoebae from the genus Acanthamoeba.

In the present work, the environmental health hazard related to FLA in dust from internal non-hospital environments, in which a large number of young and apparently healthy people circulate. On both campuses a larger frequency of cysts and trophozoites from Acanthamoeba species than Naegleria species was detected, which is in accordance with expectations $[4,17,18]$. These results may also be a consequence of the sampling being carried out more frequently in dry places, and also because Acanthamoeba is more resistant to disinfectants and environmental variations than Naegleria [19].

The frequency of amoebae detection was apparently similar in hospital and non-hospital environments $[17,18]$. Taking into account that for survival and replication FLA require to feed on microorganisms and other organic particles present on the floor $[3,25,27]$, and that such nutrients should be scarce in the internal environments investigated because of wide-spread and constant cleaning. It is a reasonable assumption that the presence of amoebae results from the constant traffic of people transporting dust to these environments. It is possible that the statistically significant difference in frequency of positive samples for amoebae between the two campuses results from the much larger number of individuals that circulate on the CDI area ( 25 times larger) than on the CVN campus.

In two of the samples isolated from different CDI campus locations, the flagellated trophozoite form of Naegleria fowleri was observed. This free-living amoeba can be found in thermal waters all over the world, and is the only species among the thirty of its genus that can cause primary amoebian meningoencephalitis in humans, a rare non-opportunistic infection, that has a fast and lethal progression. Although the infection reaches the central nervous system (CNS) through the olphactory epithelium and generally affects healthy children and young adults that have swum recently in contaminated lakes and swimming pools [26,27]: it is believed also that contamination may also occur by inhalation of contaminated dust [28].

In the absence of definitive studies to the contrary, the evaluation of free-living amoebae in different internal nonhospital environments can be considered an option for health environmental surveillance.

\section{Acknowledgements}

His work was financially supported by Conselho Nacional de Pesquisa (CNPq) grant number 301149/2003-8.

\section{References}

1. Khan N. A. Acanthamoeba: biology increasing importance in human health. FEMS Microbiol Rev; 2006; 30: 564-559.

2. Pacheco L.G., Martins A.V., A importância do estudo das amebas de vida livre. Saúde \& Ambiente em Revista 2008; 3 (1): 57-65.

3. Schuster F. L., Visvesvara G. S. Free-living amoeba as opportunistic and non-opportunistic pathogens of humans and animals. Int J Parasitol 2004; 34: 1-27

4. Rezaeian M., Niyyati M., Farnia F., Montevalli Haghi A. Isolation of Acantamoeba spp. from differente Environmental sources. Iranian J Parasitol 2008; 3(1): 44-7.

5. Visvesvara G.S., Moura H., Schuster F.L. Pathogenic and opportunistic free-living amoebae: Acanthamoeba spp., Balamuthia mandrillaris, Naegleria fowleri, and Sappinia diploidea. FEMS Immun Med Microbiol 2007; 50 (1): 1-26.

6. Marciano-Cabral F., Cabral G. Acanthamoeba spp. as agents of disease in humans. Clin Microbiol Rev 2003; 16 (2): 273-307.

7. Moura H., Salazar H. C., Fernandes O., et al. Amebas de vida-livre no intestino humano: evidências de parasitismo. Rev Inst Med Trop São Paulo, 1985 ; 27:150-6. 
8. Chimelli L., Hahm M.D., Scaravilli F., et al. Granulomatous amebic meningoencephalitis due to Leptomyxid: report of the first Brazilian case. Trans R Soc Trop Med Hyg 1992; 86: 635.

9. Campos R., Gomes M.C.D., Princenzi L.S., Stecca J. Meningoencefalite por ameba de vida livre. Apresentação do primeiro caso latinoamericano. Rev Inst Med Trop São Paulo 1977; 19: 349-351.

10. Alves, J.M.P, Gusmão, C.X., Teixeira, M.M.G., et al. Random amplified polymorphic DNA profiles as a tool for the characterization of Brazilian keratitis isolates of the genus Acanthamoeba. Braz J Med Biol Res 2000; 33: 19-26.

11. Salazar H.C., Moura H., Ramos R.T., Isolamento de amebas de vida livre a partir de água mineral engarrafada. Rev Saúde Pública 1982; 16: 261-7.

12. Moura H., Ameba de vida livre em piscinas: isolamento, identificação, potencial patogênico. Dissertação de Mestrado. Fundação Oswaldo Cruz. 1980.

13. Ramos R.T., Moura H., Salazar H.C., Isolamento de amebas de vida livre de água mineral. In: $5^{\circ}$ Congresso Brasileiro de Parasitologia. Rio de Janeiro. Resumos. pag.60.

14. Foronda A.S., Observações sobre amebas de via livre potencialmente patogênicas.Tese de Doutoramento. Instituto de Ciências Biomédias USP.1979.

15. GiazziI J.F. Contribuição para o estudo do isolamento, cultivo e manutenção das amebas de vida livre. Tese de livre-docência. Araraquara. Faculdade de Ciências Farmacêuticas da UNESP. 1996.

16. Alves D.S.M.M.Isolamento e caracterização morfologica de amebas de vida-livre em amostras do solo e água de piscine no Distrito Federal. Tese de Mestrado. Universidade de Brasília. Distrito Federal. 2006.

17. Silva M. A., Rosa J.A. Isolamento de amebas de vida livre potencialmente patogênicas em poeiras de hospitais. Rev Saúde Pública 2003; 37 (2): 242-6.
18. Carlesso A. M., Simonetti A. B., Artuso G. L., Rott M. B. Isolation and identification of potentially pathogenic free-living amoebae in samples from environments in a public hospital in the city of Porto Alegre, Rio Grande do Sul. Rev Soc Bras Med Trop 2007; 40:(3) 316-320.

19. Schuster F. L. Cultivation of pathogenic and opportunistic freeliving amebas. Clin Microbio Rev 2002; 15: 342-354.

20. Khan N. A. Pathogenicity, morphology and differentiation of Acanthamoeba. Curr Microbiol 2001; 43: 391-5.

21. PAGE F.C. An illustrated key to fresch water and soil amoeba. Cambridge, UK: Freshwater Biological Association. Scientifc Publication, 34, 1976.

22. Pussard M., Pons R. Morphologies de la paroi kystique et taxonomie du genre Acanthamoeba (Protozoa, Amoebida). Protistologica; 1977; 13: 557- 610.

23. Aufy S, Kilvington S., Mann P.G. Warshurst D.C. Improved selection of Naegleria fowlery from environment. Trans Royal Soc Med Hygiene 1986 ; 80 : 350-1.

24. De Jonckheere J., Van Dijck P., Van De Voorde H. The effect of thermal pollution on the distribution of Naegleria fowleri. Journal Hygiene 1975; 75: 7-13.

25. Greub G., Raoult D. Microorganisms resistant to free-living amoeba. Clin Microbiol Rev. 2004; 17: 413-433.

26. Martinez A.J. Free-living amebas: natural history, prevention, diagnosis, pathology, and treatment of disease. Boca Raton, USA: CRC Press, 1985.

27. Warhurst D.C. Pathogenic free-living amoebae. Parasitology Today 1985; 1 : 24-8

28. Visvesvara G.S., Maguire J.H. Pathogenic and opportunistic freeliving amebas: Acanthamoeba spp., Balamuthia mandrillaris, Naegleria fowleri, and Sappina diploidia. In: Guerrant R., Walker D.H., Weller P.F., Eds. Tropical Infectious Diseases: Principles, Pathogens and Practice. Philadelphia, USA: Churchill Livingstone, 2006. 